\title{
HTLV-1 ANTIBODIES IN SERUM AND CEREBROSPINAL FLUID IN TROPICAL SPASTIC PARAPARESIS IN BRAZIL
}

\author{
A. SPINA-FRANCA * J. A. LIVRAMENTO**- L. R. MACHADO** \\ H. R. GOMES ***- L.S. VIANNA***- L. H. M. CASTRO*** \\ J. P.S. NOBREGA ** - L. A. BACHESCHI**
}

\begin{abstract}
SUMMARY - HTLV-1 antibodies were investigated in serum and in CSF of 150 patients with neurologic disorders mainly myelopathies. The patients were considered into three groups according to the possible relationship of their disease to the presence of HTLV-1 antibodies: no relationship risk (control group), occasional risk group, and possible risk group. In this latter are $\mathbf{5 6}$ patients with crural spastic paraparesis or paraplegia of unknown etiology (SP). HTLV-1 antibodies were tested by the passive particle-agglutination method for anti-ATLA antibody detection. The search was negative in all patients of the control group, and positive (serum and/or CSF) in 16.5\% of the patients from the second group and in 55.4\% of the SP patients group. Clinical patterns in SP cases with HTLV-1 antibodies were those of tropical spastic paraparesis (TSP). CSF patterns considered (cytology, protein content and gamma-globulins rate) were different between TSF group with HTLV-1 antibodies in CSF and SP group with no HTLV-1 antibodies detection either in serum or in CSF. The difference was significant. Results of this investigation confirm the high incidence of TSP in Brazil, and bring additional indication for searching HTLV-1 antibodies in the CSF.
\end{abstract}

HTLV-1 anticorpos no soro e no líquido cefalorraqueano na paraparesia espástica tropical no Brasil.

RESUMO - Fol pesquisada a presenca de HTLV-1 anticorpos no soro e no LCR de 150 pacientes com afeccōes do sistema nervoso, particularmente mielopatias. Os pacientes foram considerados segundo très grupos, de acordo com a possivel relação entre a doença e a presença de HTLV-1 anticorpos: sem risco de relaçăo (grupo controle); grupo de risco ocasional; grupo de risco possivel. Este último abrange 56 pacientes com paraparesia ou puraplegia crural espástica de etiologia não esclarecida (PE). Foi utilizadia peara a pesquisa a técnica de aglutinaçåo passiva de partículas para anti-ATLA anticorpo, sendo obtidos os seguintea resultados: não foram detectados HTLV-1 anticorpos no grupo controle e foran detectados (soro e/Ou LCR) em 16,5\% dos pacientes do segundo grupo e em 55,4\% daqueles do terceiro grupo. O quadro clínico dos pacientes com PE e HTLV-1 anticorpos era compativel a paraparesia espática tropical (PET). Foi verificada diferença significativa quanto a dados do exame de LCR (citologia, concentração proteica e teor de globulinas gama) ao se compararem os pacientes com PET corn HTLV-1 anticorpos no LCR àqueles cum PE em que tais anticorpos não foram detectados nem no soro e nem no LCR. Os resultados deste estudo confirmam a elevada incidência da PET no Brasil \& ilustram a necessidade da pesquisa desses anticorpos também no ICR.

In the last five years it has been emphasized the retrovirus HTLV-1 serumposivity in several groups of patients with crural spastic paraparesis or paraplegia (SP). New concepts resulted on the etiology of tropical spastic paraparesis (TSP) 6,7,10,12, 14-16,23. Roman et al. rank among the first in the study of TSP patterns 19,20 . TSP is a long progressive evolution disease that attempts lower limbs asymmetrically, with

Neurology Research Center. Department of Neurology, São Paulo University Medical School: "Full Professor: ** Assistant Professor: *** Neurologist Researcher.

Dr. A. Spinafr-anca - Caixa Postal 6199 - 01051 São Paulo SP - Brasil. 
motor impairment, spasticity and sometimes autonomic dysfunctions (impaired bladder function and impotence). There is a prevalence in men, and average time of incidence usually is few years above 40 years old. Also, it has been shown that patients are from lower social groups and mulattoes 20 . Cases have been described after blood transfusion and sexual contact 9,16. Nevertheless, satisfactory data about etiopathogeny depend on further studies. The presence of this pathology in Brazil was registered in 1989 and $1990^{3-5,17}$. Studies related to cerebrospinal fluid (CSF) patterns in TSP are few and not systematized 2,8 .

Results of an investigation about HTLV-1 antibodies detection in SP patients are reported. TSP diagnosis is discussed, and also CSF composition when HTLV-1 antibodies are present.

\section{MATERIAL AND METHODS}

HITLV-1 antibodies were searched in 150 patients with neurologic disorders. Signs of spinal cord involvement occurred in all. Serum and CSF were tested in 97 patients and only in the CSF in 53. The patients were considered into three groups (Table 1) according the relationship between their disease and the presence of HTLV-1 antibodies: (1) control group, in which the antibodies presence could not be related to the disease; (2) occasional risk group, in which the antibodies presence could not justify directly the disease; (3) possible risk group, where presence of HTLV-1 antibodies could be related to the disease.. In first group are 9 patients with traumatic paraplegia. In the second are 85 patients with: nansoni schistosomiasis meningomyeloradiculitis (SMR), multiple sclerosis clinically and CSF defined (MS) MS non CSF defined (possible MS), AIDS, and other neurologic diseases (OND). In the third group are 56 patients with chronic progressive non-traumatic SP of unknown etiology. In all of them, syphilis and cysticercosis have been previously excluded by immunologic tests.

The HTLV-1 antibodies were searched once in each case in CSF (150) and in serum samples (97). Passive particle-agglutination technic for anti-ATLA antibody detection (Fujirebio, Japan) was used. As preconized, serum and CSF samples were previously diluted (1/16) and analysis of reactions was made after three hours. Results were registered as positive or negative; quantitative tests were not made. In CSF samples patterns congidered were: cytology (cells/mm3 number and cytomorphological profile), protein and glucose content $(\mathrm{mg} / \mathrm{dL}$ ), and gamma globulins participation $(\%)$ and distribution (multicional or oligoclonal) on the protein profile. Other specific antibodies (syphilis, cystictrcosis, toxoplasmosis, schistosomiasis, HIV) are mentioned when detected.

Statistical methods applied were: chi-square in the study of frequencies; Kruskall-Wallis in analysis of variance; Mann-Whituey in testing hypothesis between two variables. In all of them, non-parametric analysis was performed and $p$ values until 0.05 were considered signlficant.

\begin{tabular}{|c|c|c|c|c|c|c|c|c|c|c|c|c|}
\hline \multirow[b]{2}{*}{ Group } & \multirow[b]{2}{*}{ Diagnosis } & \multirow[b]{2}{*}{$\mathrm{n}$} & \multicolumn{2}{|c|}{ Sex } & \multicolumn{2}{|c|}{ Race } & \multicolumn{4}{|c|}{ Age } & \multicolumn{2}{|c|}{ HTLV-1 search } \\
\hline & & & $\mathbf{M}$ & F & $\mathrm{W}$ & $\mathbf{N}$ & av & $\mathrm{mn}$ & $\mathbf{m}$ & $\mathbf{M}$ & $\mathrm{S}+\mathrm{CSF}$ & CSF \\
\hline$x$ & Traumatic & 9 & 9 & 0 & 2 & 7 & 31.0 & 29 & 15 & 48 & 9 & 0 \\
\hline \multirow[t]{5}{*}{2} & SMR & 7 & 4 & 3 & 5 & 2 & 34.6 & 25 & 14 & 78 & 3 & 4 \\
\hline & MS & 8 & 7 & 1 & 8 & 0 & 39.1 & 40 & 20 & 63 & 3 & 5 \\
\hline & Poss MS & 16 & 7 & 9 & 16 & 0 & 35.4 & 31 & 18 & 64 & 12 & 4 \\
\hline & AIDS & 16 & 14 & 2 & 13 & 3 & 37.1 & 36 & 22 & 62 & 13 & 3 \\
\hline & OND & 38 & 23 & 15 & 38 & 0 & 43.6 & 43 & 10 & 80 & 16 & 22 \\
\hline 3 & SP & 56 & 35 & 21 & 39 & 17 & 44.4 & 45 & 13 & 68 & 41 & 15 \\
\hline Total & & 150 & 99 & 51 & 121 & 29 & 32.5 & 41 & 10 & 80 & 97 & 53 \\
\hline
\end{tabular}

Table 1 - Identification and distribution in groups according to the pathology of 150 patients whom HTLV-1 antibodies research was performed in serum (S) and/or in CSF. Traumatic, traumatic paraplegia; SMR, mansoni schistosomiasis meningomyeloradiculitis; $M S$, multiple sclerosis; pass MS, MS without CWF suggestive patterns; AIDS, cacquired immunodeficiency synarome; $O N D$, other neurologic diseases; SP, spastic paraplegia or paraparesis; $n$, number of cases; $M$, male; $F$, female; $W$, white; $N$, nigro or mulatto; age in years old (av, average; $m n$, median; $m$, minimum; $M$, maximum). 


\section{RESULTS}

HTLV-1 antibodies - Control group patlents did not present HTLV-1 antibodies (serum and CSF). HTLV-1 antibodies were detected in 14 cases from group 2 and in 31 from group 3. In these 45 cases the search was positive in serum and CSF in 24; positive in ser.m and negative in CSF in 14; positive only in CSF (serum invegtigation not performed) in 7 (Table 2). Four of these 7 cases were from group 3 (SP) and three from group 2. Cases (14) with HTLV-1 antibodies detected only in serum were: 7 from group 3 (SP) and 7 from group 2. The 24 cases with HTLV-1 antibodies in serum and CSF were: 20 from group 3 (SP) and 4 from group 2. Therefore, HTLV-1 antibodies were detected in serum and/or CSF in $16.5 \%$ of group 2 cases and in $55.4 \%$ of those with SP (group 3). This difference is significant $(p=0.001)$.

\begin{tabular}{|c|c|c|c|c|c|}
\hline \multirow[b]{2}{*}{ Group } & \multirow[b]{2}{*}{ Diagnosis } & \multicolumn{2}{|c|}{ Serum and CSF } & \multirow{2}{*}{$\frac{\mathrm{CSF}}{\mathrm{CSF}+}$} & \multirow[b]{2}{*}{ Total } \\
\hline & & $\underset{\mathrm{CSF}+}{\mathrm{Serum}+}$ & $\begin{array}{c}\text { Serum }+ \\
\text { CSF- }\end{array}$ & & \\
\hline \multirow[t]{4}{*}{2} & MS & 0 & 0 & 1 & 1 \\
\hline & Poss MS & 0 & 2 & 0 & 2 \\
\hline & AIDS & 3 & 2 & 1 & 6 \\
\hline & OND & 1 & 3 & 1 & 5 \\
\hline 3 & $\mathbf{S P}$ & 20 & 7 & 4 & 31 \\
\hline Total & & 24 & 14 & 7 & 45 \\
\hline
\end{tabular}

Table 2 - Distribution of the 45 cases which HTLV-1 antibodies research was positive in $\left(\right.$ Serum + ) and/or in $C B F^{\prime}\left(C S F^{\prime}+\right)$ and negative in CSF (CSF-).

TSP - The positive outcome of HTLV-1 antibodies research in $31(55.4 \%)$ of the 56 cases from group 3 (SP) allows the possibility that these patients presented TSP, realiably in those $20(64.5 \%)$ with HTLV-1 antibodies in CSF. Although the bigger rate of nigroes and mulattoes in group $3(28.6 \%)$ than in group $2(5.9 \%)$, it did not differ into group 3 among patients with or without HTLV-1 antibodies (29 and $28 \%$, respectively). Into these two subgroups men predominance was different. It was small among those with HTLV-1 antibodies (1,4:1 and 2,1:1, respectively). Also average age into these subgroups was somewhat over 40 years old, with close median vaiues (Table 3 ).

\begin{tabular}{|c|c|c|c|c|c|c|c|c|c|}
\hline \multirow{2}{*}{$\begin{array}{c}\text { Group } 3 \\
\text { SP }\end{array}$} & \multirow[b]{2}{*}{$\mathrm{n}$} & \multicolumn{2}{|c|}{ Sex } & \multicolumn{2}{|c|}{ Rlace } & \multicolumn{4}{|c|}{ Age } \\
\hline & & $\mathbf{M}$ & $\mathbf{F}$ & w & $\mathbf{N}$ & av & $\mathrm{mn}$ & $\mathbf{m}$ & $\mathbf{M}$ \\
\hline HTLV-1+ & 31 & 18 & 13 & 22 & 9 & 46.1 & 47 & 22 & 68 \\
\hline HTLV-1 - & 25 & 17 & 8 & 18 & 7 & 42.2 & 45 & 13 & 62 \\
\hline
\end{tabular}

Table 3 - Distribution of 56 patients (n) from growp 3 (SP) acconding ot sex, race and age, and the outcome of $H T L V-1$ antibodies research in CSF and/or serum (HTLV-1 + , positive result; HTLV-1-, negative result).

CSF - Patterns differed in group 3 according to HTLV-1 antibodies presence (Table 4). Among the 24 patients with HTLV-1 antibodies in the CSF predominated: slight increase in the cell number; moderate increase in the protein content; discrete or moderate increase of garnma globulins rate. In patients without HTLV-1 antibodies in CSF and in serum predominated normal cell number, normal protein content and normal gamma globulins 
rate. Differences related to these patterns were significant (Table 5). Decrease in glucose concentration was occasional and occurred indifferently in these two subgroups. Oligocional bands were observed in the subgroup with HTLV-1 antibodies. Cytomorphology did not differ. In both subgroups it was murked by lymphocytes and monocytes. Macrophages and plasma cells occurred occasionally in them, as well as neutrophil and eosinophil cells.

\begin{tabular}{|c|c|c|c|c|c|c|c|c|c|c|c|c|c|}
\hline \multicolumn{2}{|c|}{$\begin{array}{c}\text { HTLV-1 } \\
\text { antibodies }\end{array}$} & \multirow{2}{*}{$\begin{array}{c}\text { Group } 3 \\
\text { (SP) } \\
\mathbf{n}\end{array}$} & \multicolumn{3}{|c|}{ Cytology } & \multicolumn{3}{|c|}{ Protein } & \multicolumn{3}{|c|}{$\begin{array}{l}\text { Gamma } \\
\text { globulins }\end{array}$} & \multirow{2}{*}{$\begin{array}{l}\text { Glue } \\
\text { decr }\end{array}$} & \multirow{2}{*}{$\begin{array}{l}\text { Gamma } \\
\text { oligocl } \\
\text { bands }\end{array}$} \\
\hline $\mathbf{S}$ & CSF & & $\mathrm{N}$ & $\mathrm{D}$ & $\mathbf{M}$ & $\mathrm{N}$ & $\mathrm{D}$ & $\mathbf{M}$ & $\mathbf{N}$ & $\mathrm{D}$ & $\mathbf{M}$ & & \\
\hline+ & + & 20 & 8 & 11 & 1 & 5 & 4 & 11 & 8 & 5 & 7 & 4 & 4 \\
\hline ns & + & 4 & 1 & 2 & 1 & 1 & 1 & 2 & 1 & 2 & 1 & 0 & 0 \\
\hline+ & - & 7 & 5 & 2 & 0 & 2 & 1 & 4 & 6 & 1 & 0 & 0 & 0 \\
\hline- & - & 14 & 11 & 2 & 1 & 8 & 2 & 4 & 12 & 2 & 0 & 2 & 0 \\
\hline ns & - & 11 & 8 & 3 & 0 & 7 & 2 & 2 & 10 & 0 & 1 & 0 & 0 \\
\hline \multicolumn{2}{|c|}{ Total } & 56 & 33 & 20 & 3 & 23 & 10 & 23 & 37 & 10 & 9 & 6 & 4 \\
\hline
\end{tabular}

Table 4 - Distribution of the 56 cases fnom group 3, according to the presence (+) or absence (-) of HTLV-1 antibodies in serum (S) and in CSF, and CSF patterns considered: cytology $\left(N\right.$, until 4 cells $/ \mathrm{mm}^{3} ; \mathrm{D}, 4$ to $50 ; M, 50$ to 200$)$, protein $(N$, until $40 \mathrm{mg} / \mathrm{dL}$; $D, 40$ to $60 ; M, 60$ to 200), gamma globulins $(N$, until $14 \% ; D, 14$ to $20 ; M, 20$ to 35 ), glucose decrease content under $50 \mathrm{mg} / \mathrm{dL}$ (Gluc decr), amd presence of gamma globulins oligoclonal (oligocl) bands. ns, non searched.

\begin{tabular}{|c|c|c|c|c|}
\hline \multirow{2}{*}{$\begin{array}{l}\text { HTLV-1 } \\
\text { antibodies }\end{array}$} & \multirow[b]{2}{*}{ Estimatives } & \multicolumn{3}{|c|}{ CSF } \\
\hline & & $\begin{array}{c}\text { Cytology } \\
(*)\end{array}$ & $\begin{array}{l}\text { Protein } \\
(* *)\end{array}$ & $\begin{array}{c}\text { Gamma glob } \\
(* * *)\end{array}$ \\
\hline $\operatorname{csF}+$ & average & 11.8 & 56.6 & 17.8 \\
\hline \multirow[t]{2}{*}{$(n=24)$} & median & 6.5 & 56.0 & 17.3 \\
\hline & range & $0.3-84$ & $32-91$ & $9.5-31$ \\
\hline $\operatorname{CSF}-$ & average & 11.8 & 42.3 & 11.7 \\
\hline Serum - & median & 1.7 & 37.5 & 11.9 \\
\hline$(n=14)$ & range & $0.3-140$ & $30-65$ & $7.7-16.2$ \\
\hline
\end{tabular}

Table 5-CSF from group 3 (SP): summary statistics of cell/mms number, protein content $(m g / d L)$ and gamma globulins (\%); significant statistical difference: $(*), p=0.03$; $(* *)$ $p=0.01 ;(* * *), p=0.001 ; n$, sample size; + , antibodies detected; -, antibodies non detected.

Other antibodies - HIV antibodies were detected (serum and CSF) in AIDS patients, and in one of then associated to toxoplasmosis antibodieg (CSF). Mansoni schistosomiasis antibodies were found (CSF) in SMR patients. Syphilis or cysticercosis antibodies were not detected (CSF).

HTLV-1 antibodies in other diseases - vetection among patients of group 2 was more frequent in serum than in CSF (Table 6). 
HTLV-1

antibodies

Diagnosis

\begin{tabular}{cclc}
\hline \hline Serum & CSF & MS progressive spinal form & 1 \\
ns & + & AIDS associated myelopathy & 1 \\
& & Rheumatic arthritis + SP & 1 \\
Serum & CSF & Possible MS, progressive spinal form & 1 \\
+ & - & AIDS associated myelopathy & 1 \\
& & AIDS associated myelopathy + CNS toxoplasmosis & 1 \\
& & Rubella meningoencephalomyelitis & 1 \\
& & Melanoma associated myelopathy & 1 \\
& & Breast adenocarcinoma lassociated myelopathy & 3 \\
& CSF & AlDs associated myelopathy & 1 \\
\hline
\end{tabular}

Tatle 6 - Diagnosis and cases number $(n)$ in report $H T L V-1$ antibodies research $(+$, detected; -, non detected; $n s$, non searched) in serum and CSF for group 2 cases presenting other possible etiologies.

\section{COMMENTS}

Detailed studies are many in other regions 6,10,12,18,21; in Brasil, however, there are few studies on TSP incidence and patterns. Costa et al.5 reported 10 cases observed in Brazilian northeast region that fulfill clinical criteria for diagnosis; eventhough immunologic evidence of HTLV-1 antibodies was not investigated. Cortes et al.4 in a serologic screening among AIDS high risk patients also investigated HTLV-1 antibodies, detected chiefly in hemophiliac patients; SP is not mentioned. Castro et al.3 studied 16 cases with SP and $13 \mathrm{MS}$ cases with spinal cord involvement; HTLV-1 serumpositivity was detected in $6 \mathrm{SP}$ patients and in one MS case. In the Amazon Basin, Nakauchi et al.17 registered high incidence of HTLV-1 antibodies in serum for natives $(10-39 \%)$ and for patients with neoplasies (about $23 \%$ ). In the present study serum and CSF, were tested in patients of three risk groups.

Cases from group 1 presented traumatic paraplegia, and detection of HTLV-1 intibodies among them obviously could not be related to etiopathogeny. Cases from zroup 3 presented chronic and progressive spastic paraparesis or paraplegia of unknown etiology, and HTLV-1 antibodies evidence among them could be diagnostics for TSP. Among cases of group 2 HTLV-1 antibodies detection could bring additional diagnostic information. HTLV-1 antibodies were not detected in the cases of group 1 and their detection in cases of group 3 significantly differs from that observed for group 2 . These data make possible the identification of TSP cases among patients of group 3. As a result, priorly diagnosed cases of «idiopathic» myelopathy now can have the diagnosis of TSP when HTLV-1 antibodies are detected in them. To exemplify the resulting diagnostic benefits data on a series of 353 cases of myelopathy studied before, are illustrative: $36.7 \%$ of them remained with diagnosis of «idiopathic» myelopathy 23 . In the present series the detection of HTLV-1 antibodies in $55.4 \%$ of SP cases allows for them the diagnosis of TSP, according to criteria accepted at present time. Diagnosis was suggested by clinics and confirmed by HTLV-1 antibodies detection. Safety diagnosis in this group of 31 patients with TSP was established in the 20 cases with specific antibodies in the CSF $(64.5 \%)$. The technic is sensible and specific and in CSF it was used the same methodology preconized for serum, including the 1:16 sample dilution. This procedure helped the reaction specificty in CSF, because no doubtful results were registered. Comparing our results with those of Rodgers-Johnson et al.18 and Roman et al.19-21, in Caribbean region and in Colombia, we verify similar high rates for HTLV-1 antibodies occurrence among SP patients. Our data also indicate a predominance of TSP in males, a smaller participation of 
white patients and an average age somewhat over 40 years old, that agree with other studies $6,11,12,20$.

Presence of HTLV-1 antibodies in serum and in CSF has been noticed in patients with other diseases, like AIDS, neoplasia, and MS 1,4,8,11. In this study, this is illustrated by cases from group 2. Search for HTLV-1 among them was positive in CSF only in 4 from the 14 cases, three of them with AlDS. In none of cases studied syphilis antibodies were detected, as frequently related in literature when HTLV-1 antibodies are detected in serum 18,20. This aspect is pointed out because no patients with syphilis antibodies in serum and/or CSF were included in this study.

Some differences were found about CSF patterns. Those TSP patients with HTLV-1 antibodies in CSF present hypercytosis more frequent and intensively than those with SP with no antibody detected. The same is true for the increase in the protein content and its intensity, as well as for the increase of gamma globulins rate. So, in SP cases presenting a slight or discrete hypercytosis, discrete or moderate increase in protein content and increase in gamma globulin rate, it is fully justified the searching of HTLV-1 antibodies in the aiming of TSP diagnosis. The finding of oligoclonal bands in CSF gamma globulins distribution, should be suggestive of $M S$, but was observed in four TSP cases. On the other hand, the increase of gamma globulins rate in the CSF can bring doubts on the diagnosis of MS spinal form, as illustrated by two such cases of group 2.

Patients with HTLV-1 antibodies in CSF can present local immune phenomena which can occur in association with slight blood-brain barrier impairment phenomena. CEll contingent behaviour presents features of chronic inflammatory response like in MS and in SMR. Protein concentration usually is higher than in patients with AIDS associated myelopathy and SMR. Gamma globulins behaviour resembles patterns verified in pathologies accompanied by local immune response, like AIDS, MS and SMR. Otherwise, in SP patients with no evidence of pathology that can explain the clinical features, HTLV-1 antibodies investigation in serum and chiefly in CSF is indicated also in this country to verify the diagnostic probability of TSP.

Acknowledgement - The authors acknowledge Dr. Gustavo C. Roman (National Institute of Health, Bethesda, USA) who kindly provided material for HTLV-1 antibodies tests (Fujirebio, Japan).

\section{REFERENCES}

1. Aboulafia DM, Saxton EM. Koga H, Diagne A, Rosenblatt JD - A patient with progressive myelopathy and antibodies to human $T$-cell leukemia virus type 1 and human immunodeficiency virus type 1 in serum and cerebrospinal fluid. Arch Neurol $47: 477,1990$.

2. Bhagavati S, Ehrlich G, Kula RW, Kwork S, Sninsky J, Udani V, Poiesz B - Detection of human T-cell lymphoma/leukemia type I DNA and antigen in spinal fluid and blood of patients with chronic progressive myelopathy. N Engl J Med 318:1141, 1988.

3. Castro LHM, Chaves CJ, Callegaro D, Nobrega JPS, Scaff M - HTLV-1 associated myelopathy in Brazil: a preliminary report. Arq NeuroPsiquiat (São Paulo) 47:501, 1989.

4. Cortes E, Detels R, Aboulafia D, Li XL, Moudgil T, Alam M, Bonecker C, Gonzaga A, Oyafuso L, Tondo $\mathbf{M}$ Boite C, Hammaershlak $\mathbf{N}$, Capitani C, Slamon DJ, Ho DD HIV-1, HIV-2 and H'TLV-1 infection in high-risk groups in Brazil. N Engl J Med $320: 953,1989$.

5. Costa CMC, Salgueiro MR, Carton H, Vale OC, Arruda AM - 'Tropical spactic paraparesis in northeastern Brazil. Arq Neuro-Psiquiat (São Paulo) 47:134, 1989.

6. Cruickshank JK, Richardson JH, Morgan O StC, Porter J, Klenerman P, Knight J, Newell AL, Rudge P, Dalgleish AG - Screening for prolonged incubation of HTLV-1 infection in british and jamaican relatives of british patients with tropical spactic partaparesis. Br Med J 300:300, 1990.

7. Cruickshank JK, Rudge P, Dalgleish AG, Newton M, McLean BN, Barnard RO, Kendall BE, Miller DH - Tropical spastic paraparesis and human $T$ cell lymphotropic virus type 1 in the United Kingdom. Brain 112:1057, 1989. 
8. DeRossi A, Gallo P, Tavolato B, Callegaro L, Chieco-Bianchı L - Search for HTLV-1 and LAV/HTLV-III antlbodies in serum and CSF of multiple sclerosis patients. Acta Neurol scand $74: 161,1986$.

9. Gout O, Baulac M. Gessain A, Semah F, Saal F, Péries J, Cabrol C, Foucault-Fretz C, Laplane D, Sigaux F, DeThe $G-$ Rapid development after HTLV-1 infection acquired by transfusion during cardiac transplantation. N Engl J Med 322:383, 1990.

10. Gout O Gessain A, Bolgert F, Saal F, Tournier-Lasserve E, Lasneret J, Caudie C, Brunet P. DeThe G, Lhermitte F, Lyon-Caen O - Chronic myelopathies associated with human T-lymphotropic virus type I: a clinical, serologic, and immunovirologic study of ten patients in France. Arch Neurol 46:255, 1989.

11. Haaheim LR, Gronning $\mathbf{M}$, Nyland $\mathbf{H}-$ Antibodies in sera from norwegian multiple sclerosis patients and the general population reacting with HTLV-1. APMIS 97:767, 1989.

12. Iwasaki $\mathbf{Y}$ - Pathology of chronic myelopathy associated with HTLV-1 infection (HAMTSP). J Nel.rol Sci 96:103, 1990.

13. Jacobson S, Gupta A, Mattson D, Mingioli E, McFarlin DE - Immunological studies in tropical spastic paraparesis. Ann Neurol 27:149, 1990.

14. Johnson RT. McArthur JC - Myelopathies and retroviral infections. Ann Neurol 21:113, 1987.

15. Kayembe K Goubau P, Desmyter J, Vlietinck R, Carton H - A cluster of HTLV-1 associated tropical spastic paraparesis in Equateur (Zaire): ethnic and familial distribution. J Neurol Neurosurg Psychiat 53:4, 1990.

16. Murphy EL, Figueroa JP, Gibbs WN, Brathwaite A, Holding-Cobham M, Waters D, Cranston B, Hanchard B, Blattner WA - Sexual transmission of human T-lymphotropic virus type 1 (HTLV-1). Ann Intern Med 111:555, 1989.

1i. Nakauchi CM, Linhares AC, Maruyama K, Kanazaki LI, Macedo JE, Azevedo VN, Casseb JSR - Prevalence of human ' 1 cell leukemia virus I (HTLV-1) antibody among populations living in the Amazon region of Brazil: preliminary report. Mem Inst Osw Cruz, (Rio) 85:29, 1990.

18. Rodgers-Johnson P, Morgan O StC, Mora C, Sarin P, Ceroni P, Piccardo P, Garruto RM, Gibbs CJ Jr, Gajdusek DC - The role of HTLV-1 in tropical spastic paraparesis in Jamaica. Ann Neurol 23(suppl):121, 1988.

19. Román GC - Mielopatias y mieloneuropatias tropicales. Bol Of Sanit Panam 101:452, 1986.

20. Román GC - The neuroepidemiology of tropical spastic paraparesis. Ann Neurol 23(suppl):113, 1988.

21. Román GC, Román LN - Tropical spastic paraparesis: a clinical study of 50 patients from Tumaco (Colombia) and review of the worldwide features of the syndrome. J Neurol Sci $87: 121,1988$.

22. Román GC, Spencer PS, Schoenberg BS - Tropical myeloneuropathies: the hidden endemias. Neurology 35:1158, 1985.

23. Spina-França A Salum PNB, Limongl JCP, Berger A, Losso ER - Mielopatias: aspectos diagnosticos. Árq Neuro-Psiquiat (Săo Paulo) 38:360, 1980. 